\title{
Effect of Storage in Water and Thermocycling on Hardness and Roughness of Resin Materials for Temporary Restorations
}

\author{
Jerusa Cleci de Oliveira ${ }^{\mathrm{a}}$, Glauber Aiello ${ }^{\mathrm{a}}$, Bruna Mendes ${ }^{\mathrm{a}}$,Vanessa Migliorini Urban ${ }^{\mathrm{b}}$, \\ Nara Hellen Campanha ${ }^{\mathrm{b}}$, Janaina Habib Jorge ${ }^{\mathrm{b}, *}$ \\ ${ }^{a}$ Undergraduate Student, Department of Dentistry, Ponta Grossa State University, \\ Ponta Grossa, PR, Brazil \\ bAssistant Professor, Department of Dentistry, Ponta Grossa State University, \\ Ponta Grossa, PR, Brazil
}

Received: February 26, 2010; Revised: May 12, 2010

\begin{abstract}
Purpose: This study evaluated the effect of storage in water and thermocycling on hardness and roughness of resin materials for temporary restorations. Material and Methods: Three acrylic resins (Dencor-De, Duralay-Du, and Vipi Cor-VC) were selected and one composite resin (Opallis-Op) was used as a parameter for comparison. The materials were prepared according to the manufacturers' instructions and were placed in stainless steel moulds (20 $\mathrm{mm}$ in diameter and $5 \mathrm{~mm}$ thick). Thirty samples of each resin were made and divided into three groups $(n=10)$ according to the moment of Vickers hardness $(\mathrm{VHN})$ and roughness (Ra) analyses: C (control group): immediately after specimen preparation; $\mathrm{Sw}$ : after storage in distilled water at $37^{\circ} \mathrm{C}$ for 24 hours; Tc: after thermocycling ( 3000 cycles; $5-55^{\circ} \mathrm{C}$, 30 seconds dwell time). Data were submitted to 2-way ANOVA followed by Tukey's test $(\alpha=0.05)$. Results: Op resin had higher surface hardness values $(\mathrm{p}<0.0001 ; 25.4 \pm 3.4)$ than the other ones $(\mathrm{De}=4.5 \pm 0.6 ; \mathrm{Du}=5.5 \pm 0.4 ; \mathrm{VC}=6.1 \pm 0.9)$. There was no statistical difference $(\mathrm{p}>0.05)$ in roughness among materials $(\mathrm{De}=0.31 \pm 0.07 ; \mathrm{Du}=0.51 \pm 0.20 ; \mathrm{VC}=0.41 \pm 0.15 ; \mathrm{Op}=0.42 \pm 0.18$ ). Storage in water did not change hardness and roughness of the tested materials $(p>0.05)$. There was a significant increase in roughness after thermocycling $(\mathrm{p}<0.05)$, except for material $\mathrm{Du}$, which showed no significant change in roughness in any evaluated period $(p=0.99)$. Conclusion: Thermocycling increased the roughness in most tested materials without affecting hardness, while storage in water had no significant effect in the evaluated properties.
\end{abstract}

Keywords: acrylic resin, composite resin, Vickers hardness, surface roughness, thermocycling

\section{Introduction}

During prosthetic planning, several aspects, such as the mechanical, biological and esthetic principles of tooth preparation, must be respected to obtain successful oral rehabilitation. Temporary restorations should be inserted immediately after tooth preparation to reestablish esthetics and function, as well as to protect the adjacent periodontium and pulp tissue against exogenous damage. Furthermore, temporary restorations are used to assist diagnosis and planning oral rehabilitation, correcting changes in the occlusal plane, reestablishing occlusal vertical dimension, providing harmonious gingival contour and evaluating color, shape and size of the definitive restorations ${ }^{1}$.

Temporary restorations may be made with polymethyl methacrylate, polyethyl methacrylate-based resins and bis-acrylic resin composites, which have an organic matrix/filler content with a chemical composition similar to that of resin composites ${ }^{2-4}$. It has been shown that bis-acrylic resin composites provide greater resistance to dissolution, fracture resistance, flexural strength, better anatomic contours and marginal fit when compared with acrylic resins $s^{2,5}$. However, some studies have shown that acrylic resins exhibit a smoother surface than bis-acrylic resin composites after both polymerization ${ }^{2,3}$ and surface polishing ${ }^{2,3,6}$.

According to Diaz-Arnold et al. ${ }^{7}$, surface hardness could be related to degradation of the restoration, since this property is directly related to the quality of polymerization and cross-link density ${ }^{8,9}$ of the material, and specifically for resin composites, to its filler content ${ }^{10}$.
The presence of a rough surface on the temporary restoration favors bacterial adhesion and dental biofilm formation, resulting in gingival inflammation and periodontal bone resorption ${ }^{11}$. Furthermore, a rougher surface affects light reflection and brightness of the restorative material, as well as favors discoloration and staining ${ }^{12}$. Ayuso-Montero et al. ${ }^{2}$ also reported that the surface of the temporary restoration should be smooth enough to be comfortable, esthetic, and able to avoid staining and biofilm accumulation.

It has been demonstrated a decrease in the mechanical properties of the materials used for temporary restorations following prolonged exposure to humidity ${ }^{13-17}$. In addition, the temperature of the mouth varies considerably by the intake of hot and cold food and drinks, resulting in stress at the interface tooth-restoration. As a consequence, the stability of the cement may be compromised leading to microleakage and dissolution of the cement. Furthermore, constant temperature range between 4 and $60{ }^{\circ} \mathrm{C}$ might lead to fatigue or stress, which impair some material properties such as cohesive, compressive, and shear strength, as well as hardness and roughness.

Other factors may affect the surface hardness and roughness of temporary restorations, such as processing and polishing techniques, power to liquid ratio, and time of use ${ }^{18}$. Additionally, Silva Filho et al. ${ }^{19}$ verified that roughness of some chemically activated acrylic resins increased after thermocycling. Therefore, temporary restorations should not remain in the oral cavity for long time. 
Considering that some rehabilitation treatments require the use of temporary restorations for a longer period of time, the aim of this study was to assess the effect of storage in water and thermocycling on the Vickers hardness and roughness of three autopolymerizing acrylic resins and one microhybrid composite resin. It was hypothesized that the evaluated properties would (1) vary among different materials and (2) change with storage in water and thermocycling.

\section{Material and Methods}

\subsection{Materials used}

Three autopolymerizing acrylic resins used for temporary restorations (Dencor, Duralay, and Vipi Cor) and one composite resin (Opallis), as a parameter for comparison, were selected (Table 1).

\subsection{Specimen fabrication}

The acrylic resins were mixed in accordance with the manufacturers' instructions (Table 1) and were inserted into hollow, disk-shaped stainless steel moulds with the dimensions of $20 \mathrm{~mm}$ in diameter and $5 \mathrm{~mm}$ thick. The composite resin test specimens were obtained by inserting and photopolymerizing them in the same matrix. During the polymerization, the test specimens were manually pressed between two Mylar strips and glass plates. After the polymerization time (Table 1), the specimens were removed with a plunger. The test specimens were then submitted to finishing using 600-grit silicon carbide paper to remove superficial irregularities. Polishing procedure was performed in a polishing lathe (Nevoni, São Paulo, Brazil) using pumice stone (Labordent, São Paulo, Brazil) along with white, black brushes, and felt tip for 1 minute each, respectively. Final polishing was performed with a flannel wheel and Spanish white paste (Labordent, São Paulo, Brazil) during 1 minute.

\subsection{Experimental groups}

The test specimens $(n=10)$ were submitted to one of the experimental conditions:

1. Control (C): specimens were tested immediately after preparation;

2. Storage in water $(\mathrm{Sw})$ : storage in distilled water at $37^{\circ} \mathrm{C}$ for 24 hours $^{20}$.

3. Thermocycling (Tc): thermal cycles were made in a thermocycling machine (model MSCT-3, Marcelo Nucci-ME, São Carlos, SP, Brazil) and consisted of 3000 cycles at 5 and $55^{\circ} \mathrm{C}$ with a 30 -second dwell time ${ }^{21}$.

\subsection{Vickers hardness and roughness}

Hardness measurements (VHN) were made with a microhardness indenter machine (Micromet 2100; Buehler, Lake Bluff, Illinois, USA) at a $25 \mathrm{gf}$ load for 30 seconds. Twelve indentations were made on each specimen, and then the mean value was calculated.

The superficial roughness was evaluated using a surface roughness tester (Surftest SJ-401, Mitutoyo Sul Americana Ltda, Santo Amaro, SP, Brazil) with a standard cut-off value of $0.8 \mathrm{~mm}$ and a speed of $0.5 \mathrm{~mm} / \mathrm{s}$. Mean surface roughness ( $\mathrm{Ra}$ ) was measured in 5 areas on each specimen. The results were submitted to two-way analysis of variance, followed by Tukey's test $(\alpha=.05)$.

\section{Results}

A significant materials-experimental groups interaction indicated that experimental condition influenced both hardness and roughness of the tested materials (Table 2).

For hardness (Table 3), Dencor control specimens showed the lowest mean value $(\mathrm{p}<0.05)$. After storage in water, Dencor and Duralay acrylic resins demonstrated the lowest mean values $(\mathrm{p}<0.05)$. After thermocycling, there was no significant difference among the autopolymerizing acrylic resins $(p>0.05)$. For all the experimental groups, the composite resin exhibited the highest Vickers hardness values $(\mathrm{p}<0.0001)$.

For roughness (Table 4), results demonstrated that there was no significant difference $(\mathrm{p}>0.05)$ among the materials in the control group. Furthermore, the surface roughness of the materials evaluated was not changed after storage in water $(p>0.05)$. After thermocycling, there was an increase in the surface roughness of the acrylic resins Dencor $(p<0.0001)$ and Vipi Cor $(p=0.0003)$ and of the composite resin Opallis $(\mathrm{p}=0.0017)$. The surface roughness of Duralay acrylic resin was not changed by thermocycling $(\mathrm{p}=0.9926)$.

\section{Discussion}

This in vitro study simulated the use of temporary restorations for a period of three years, since each 1000 thermocycling represent the use of a fixed prosthesis for one year ${ }^{22}$. Storage in water during 24 hours was tested because in the indirect fabrication technique, temporary restorations should remain stored in water until cementation onto the tooth preparations.

Table 1. Materials evaluated in this study.

\begin{tabular}{|c|c|c|c|c|c|}
\hline Product & Manufacturer & Type & $\begin{array}{l}\text { Polymerization } \\
\text { time }\end{array}$ & $\begin{array}{l}\text { Powder / } \\
\text { Liquid ratio }\end{array}$ & Composition \\
\hline Dencor & $\begin{array}{l}\text { Clássico LTDA, } \\
\text { São Paulo, SP, Brazil }\end{array}$ & $\begin{array}{l}\text { Autopolymerizing } \\
\text { acrylic resin }\end{array}$ & 8 minutes & $20 \mathrm{~g} / 10 \mathrm{~mL}$ & $\begin{array}{l}\text { Powder: PMMA, pigments, benzoyl peroxide; } \\
\text { Liquid: MMA, DMT, EGDMA }\end{array}$ \\
\hline Duralay & $\begin{array}{l}\text { Reliance Dental Mfg Co., } \\
\text { Worth, USA }\end{array}$ & $\begin{array}{l}\text { Autopolymerizing } \\
\text { acrylic resin }\end{array}$ & 8 minutes & $20 \mathrm{~g} / 10 \mathrm{~mL}$ & $\begin{array}{l}\text { Powder: MMA copolymer, dialkyl phthalate, } \\
\text { pigments, benzoyl peroxide; } \\
\text { Liquid: MMA, DMT }\end{array}$ \\
\hline Vipi Cor & $\begin{array}{l}\text { Dental Vipi, } \\
\text { Pirassununga, SP, Brazil }\end{array}$ & $\begin{array}{l}\text { Autopolymerizing } \\
\text { acrylic resin }\end{array}$ & 5 minutes & $15 \mathrm{~g} / 7.5 \mathrm{Ml}$ & $\begin{array}{l}\text { Powder: PMMA, pigments, benzoyl peroxide; } \\
\text { Liquid: MMA, DMT, EGDMA }\end{array}$ \\
\hline Opallis & $\begin{array}{l}\text { FGM Produtos } \\
\text { Odontológicos, } \\
\text { Joinville, SC, Brazil }\end{array}$ & $\begin{array}{l}\text { Micro-hybrid } \\
\text { composite resin }\end{array}$ & $\begin{array}{l}40 \text { seconds } \\
\text { for each } 2 \mathrm{~mm} \\
\text { increment }\end{array}$ & - & $\begin{array}{l}\text { BisGMA, BisEMA, TEGDMA } \\
\text { (resin matrix }=21-22.5 \% \text { ) and barium } \\
\text { glass, aluminum silicate and silica dioxide } \\
\text { (filler }=77.5-79 \% \text { weight) }\end{array}$ \\
\hline
\end{tabular}

PMMA = polymethyl methacrylate; MMA = methyl methacrylate; DMT = dimethyl p-toluidine; EGDMA = ethylene glycol dimethacrylate; BisGMA = bisphenol A diglycidyl ether methacrylate; BisEMA = bisphenol A polyethylene glycol diether dimethacrylate; TEGDMA = triethylene glycol dimethacrylate. 
Table 2. Two-way ANOVA with materials and experimental conditions as independent variables for both hardness and roughness.

\begin{tabular}{cccc}
\hline Source & df & \multicolumn{2}{c}{$p$-value } \\
\cline { 3 - 4 } & & $\begin{array}{c}\text { Vickers } \\
\text { hardness }\end{array}$ & Roughness \\
\hline Materials (A) & 3 & $<0.0001$ & 0.0033 \\
Experimental condition (B) & 2 & 0.5293 & $<0.0001$ \\
Interaction $(\mathrm{A} \times \mathrm{B})$ & 6 & 0.0015 & $<0.0001$ \\
\hline
\end{tabular}

Table 3. Vickers Hardness means $(\mathrm{VHN}) \pm$ standard deviations for the experimental groups.

\begin{tabular}{crrr}
\hline & \multicolumn{1}{c}{$\mathrm{C}$} & \multicolumn{1}{c}{$\mathrm{Sw}$} & \multicolumn{1}{c}{$\mathrm{Tc}$} \\
\hline Opallis & $25.6 \pm 3.4 \mathrm{Ac}$ & $24.0 \pm 2.3 \mathrm{Ac}$ & $16.3 \pm 1.4 \mathrm{Ab}$ \\
Vipi Cor & $6.1 \pm 0.9 \mathrm{Aa}$ & $6.4 \pm 0.8 \mathrm{Aa}$ & $6.4 \pm 0.8 \mathrm{Aa}$ \\
Duralay & $5.5 \pm 0.4 \mathrm{Aa}$ & $4.8 \pm 0.7 \mathrm{Ab}$ & $5.3 \pm 0.3 \mathrm{Aa}$ \\
Dencor & $4.5 \pm 0.6 \mathrm{Ab}$ & $5.0 \pm 0.8 \mathrm{Ab}$ & $5.4 \pm 0.8 \mathrm{Aa}$ \\
\hline
\end{tabular}

Horizontally, means with identical capital letters were not significantly different ( $p>0.05)$. Vertically, means with identical small letters were not significantly different $(\mathrm{p}>0.05)$.

Table 4. Roughness means $(\mu \mathrm{m}) \pm$ standard deviations for the experimental groups.

\begin{tabular}{cclc}
\hline & $\mathrm{C}$ & \multicolumn{1}{c}{$\mathrm{Sw}$} & $\mathrm{Tc}$ \\
\hline Opallis & $0.42 \pm 0.18 \mathrm{Aa}$ & $0.46 \pm 0.22 \mathrm{Aab}$ & $0.83 \pm 0.21 \mathrm{Ba}$ \\
Vipi Cor & $0.41 \pm 0.15 \mathrm{Aa}$ & $0.58 \pm 0.14 \mathrm{Aa}$ & $0.95 \pm 0.35 \mathrm{Ba}$ \\
Duralay & $0.51 \pm 0.20 \mathrm{Aa}$ & $0.50 \pm 0.16 \mathrm{Aab}$ & $0.43 \pm 0.18 \mathrm{Ab}$ \\
Dencor & $0.31 \pm 0.07 \mathrm{Aa}$ & $0.31 \pm 0.08 \mathrm{Aab}$ & $0.81 \pm 0.29 \mathrm{Ba}$ \\
\hline
\end{tabular}

Horizontally, means with identical capital letters were not significantly different $(p>0.05)$. Vertically, means with identical small letters were not significantly different $(\mathrm{p}>0.05)$.

The tested hypotheses that hardness and roughness would vary among different brands and would change with storage in water and thernocycling were partially proved. There was no significant difference among the materials in the control and the storage in water groups for roughness. Storage in water did not change both hardness and roughness values of the materials and thermocycling did not affect the hardness of the materials and the roughness of Duralay acrylic resin.

Regarding the hardness, the composite resin showed higher values than the acrylic resins in all the experimental groups. These results may be explained by the difference in composition between the two types of material. The composition of Opallis resin composite presents as organic matrix BisGMA, BisEMA and TEGDMA monomers and as filler particles barium glass, aluminum silicate and silica dioxide (77.5 to $79 \%$ ). On the other hand, the acrylic resins are basically composed of MMA monomers and EGDMA as a crosslinking agent, with the exception of Duralay resin that does not have a crosslinking agent in its composition and presents a plasticizer (dialkyl phthalate).

It has been reported that surface hardness of composite resins is influenced by both the organic matrix (monomers) and the inorganic filler ${ }^{10,23}$. With regard to the organic matrix, hardness depends on the density and structure of the polymer formed ${ }^{23}$ and the degree of conversion after the polymerization ${ }^{10}$. It is known that the presence of aromatic groups in the monomers BisGMA and BisEMA provides a polymeric structure with higher rigidity ${ }^{24}$. Hardness has also been used as an indirect method to measure the degree of conversion of resins: the higher the degree of conversion, the higher the hardness values $^{23}$. Moreover, the use of bifunctional monomers such as EGDMA and TEGDMA ${ }^{10}$ to form crosslinked chains improves the hardness values. Regarding the inorganic filler, the hardness values obtained are also dependent on the volume added to the material. When the quantity of particles increases, the surface hardness of the material also increases ${ }^{10,23,25}$. Therefore, it may be suppose that the quality of polymerization of the composite resin with respect to the polymer density and the degree of conversion obtained was superior to that of the acrylic resins tested.

A decrease in surface hardness could be expected after storage in water and thermocycling due to water absorption. The action of the water molecules inside the polymeric structure has been described as plasticizing effect ${ }^{3,26}$ and the decrease in hardness would be associated with the reduction in the interchain interactions ${ }^{26}$. Furthermore, considering that the temporary restoration will be submitted to temperature changes inside the mouth, the restorative material could undergo fatigue or stress, similar to the application of cyclic loads from the cumulative effect of shrinkage and expansion. One of the harmful consequences of this phenomenon would be the decrease in the hardness values ${ }^{27}$. However, the hardness of the evaluated resins did not change neither after storage in water nor after thermocycling. It has been reported that polymeric chains with high crosslink density decrease water absorption of the material due to the reduction of the free space. Moreover, in materials with a denser polymer network, less water absorption is expected. The fact that the experimental conditions did not affect the hardness values may be explained by the presence of crosslinked chains in the polymeric structure of the acrylic resins Dencor and Vipi Cor and the composite resin Opallis. In spite of Duralay acrylic resin does not have crosslinking agents in its composition, one could suppose that this material has a denser polymeric structure. However, further studies are needed to confirm this assumption. In addition, residual monomer molecules acting as plasticizers ${ }^{28}$ may have been released ${ }^{29}$ during the storage period, thus compensating the plasticizer effect of water absorption ${ }^{30}$, although this was not assessed in this study.

With regard to the roughness results, no significant differences were observed among the acrylic resins evaluated and the composite resin used as a parameter for comparison. In another study ${ }^{31}$, there were also no significant differences in the roughness of the acrylic resins Dencor, Duralay and Vipi Cor. The study of Şen et al. ${ }^{3}$ showed that the methacrylate-based resin specimens showed smoother surfaces than the bis-acrylic composite specimens. This fact was related to the homogeneous composition of the acrylic in contrast of the heterogeneous composition of the composite. Although there were differences in the chemical composition of the acrylic resins and the composite resin evaluated, the fact that the surface roughness of the materials did not differ may be explained by the standard polishing procedure performed in all specimens.

An increase in the surface roughness values of all the materials could have been expected after specimens had been submitted to the experimental conditions because water absorption and solubility result in a variety of chemical and physical processes, such as the release of substances that did not react ${ }^{29}$ and the formation of byproducts by hydrolytic degradation, affecting the structure as well as the biocompatibility ${ }^{32,33}$ of the polymeric materials ${ }^{26}$. Particularly, exposing composite materials to water has been shown to degrade dental composites due to the degradation of filler particles, the weakening of polymer matrix or the debonding of filler-matrix interfaces ${ }^{34}$. However, an increase in surface roughness was only observed after thermocycling for Dencor, Vipi Cor and Opallis products. Only Duralay acrylic resin did not undergo the influence of thermocycling. This result is in agreement with Silva Filho et al. ${ }^{19}$, 
who observed that Duralay acrylic resin showed low surface change after thermocycling, probably due to its high density by the presence of smaller and more regular pre-polymeric particles compared with the other acrylic resins.

Although the absorption of water is reduced in materials with high filler content, the increase in the roughness of the composite resin Opallis after thermocycling may be attributed to the hydrolysis of silane coupling agents as well as the stress at the filler-matrix interface ${ }^{4,35}$. As a consequence, the filler particles located at the surface of the material would debond and the grooves created would promote the increase in the roughness, as observed in this study.

The increase in surface roughness suggests that in clinical conditions, considerable discomfort to the patient and risk for periodontal diseases by the accumulation of biofilm on the temporary restoration may also increase ${ }^{36,37}$. According to Bollen et al. ${ }^{38}$, surface roughness values higher than $0.2 \mu \mathrm{m}$ facilitate microbial adhesion both in vitro and in vivo studies. Although the results exhibited roughness higher than $0.2 \mu \mathrm{m}$, the materials evaluated in this study may be considered as materials with low roughness according to Zissis et al. ${ }^{39}$, once the materials' roughness ranged from 0.7 to $3.4 \mu \mathrm{m}$. However, the prolonged use of temporary restorations made with composite resin or acrylic resin should be avoided in order to reduce microbial colonization caused by the presence of rougher material surfaces.

Although thermocycling simulates aging by submitting materials to extreme temperatures, temporary restorations in the clinical condition are exposed to the detrimental effects of food, beverages, saliva components, and to the mechanical action of chewing and brushing. Therefore, these aspects should be considered in future investigations.

\section{Conclusion}

Within the limitations of this in vitro study, it can be concluded that:

1. Storage in water had no significant effect in the hardness and the roughness of the tested materials.

2. Thermocycling did not change the hardness of the tested materials.

3. Thermocycling increased the roughness in most tested materials, with the exception of Duralay which was not affected by thermocycling.

4. Dencor acrylic resin and Opallis composite resin showed the lowest and the highest hardness values, respectively.

5. Surface roughness values did not differ for the tested materials in the control group.

\section{References}

1. Rosenstiel SP, Land MP and Fujimoto J. Contemporary fixed prosthodontics. $2^{\text {nd }}$ ed. St. Louis: Mosby; 1995. p. 825-9.

2. Ayuso-Montero R, Martinez-Gomis J, Lujan-Climent M, Salsench J and Peraire M. Influence of matrix type on surface roughness of three resins for provisional crows and fixed partial dentures. Journal of Prosthodontics. 2009; 18(2):141-4.

3. Şen $\mathrm{D}$, Goller $\mathrm{G}$ and Issever $\mathrm{H}$. The effect of two polishing pastes on the surface roughness of bis-acryl composite and methacrylate-based resins. The Journal of Prosthetic Dentistry. 2002; 88(5):527-32.

4. Balkenhol M, Köhler H, Orbach K and Wöstmann B. Fracture toughness of cross-linked and non-cross-linked temporary crown and fixed partial denture materials. Dental Materials. 2009; 25(7):917-28.

5. Yap AU, Mah MK, Lye CP and Loh PL. Influence of dietary simulating solvents on the hardness of provisional restorative materials. Dental Materials. 2004; 20(4):370-6.
6. Haselton DR, Diaz-Arnold AM and Dawson DV. Effect of storage solution on surface roughness of provisional crown and fixed partial denture materials. Journal of Prosthodontics. 2004;13(4):227-32.

7. Diaz-Arnold AM, Dunne JT and Jones AH. Microhardness of provisional fixed prosthodontic materials. The Journal of Prosthetic Dentistry. 1999; 82(5):525-8.

8. Soh MS and Yap AU. Influence of curing modes on crosslink density in polymer structures. Journal of Dentistry. 2004; 32(4):321-6.

9. Yap AU, Soh MS, Han TT and Siow KS. Influence of curing lights and modes on cross-link density of dental composites. Operative Dentistry. 2004; 29(4):410-5.

10. Ferracane JL, Berge HX and Condon JR. In vitro aging of dental composites in water-Effect of degree of conversion, filler volume, and filler/matrix coupling. Journal of Biomedical Materials Research. 1998; 42(3):465-72.

11. Burgers R, Rosentritt $M$ and Handel G. Bacterial adhesion of Streptococcus mutans to provisional fixed prosthodontic material. The Journal of Prosthetic Dentistry. 2007; 98(6):461-9.

12. Sexson JC and Phillips RW. Studies on the effect of abrasives on acrylic resins. The Journal of Prosthetic Dentistry. 1951; 1(4):454-71.

13. Chadwick RG, McCabe JF, Walls AW and Storer R. The effect of storage media upon the surface microhardness and abrasion resistance of three composites. Dental Materials. 1990; 6(2):123-8.

14. Geurtsen W, Leyhausen G and Garcia-Godoy F. Effect of storage media on the fluoride release and surface microhardness of four polyacid-modified composite resins (“compomers"). Dental Materials. 1999; 15(3):196-201.

15. Sarrett DC and Ray S. The effect of water on polymer matrix and composite wear. Dental Materials. 1994; 10(1):6-10.

16. Kawano F, Ohguri T, Ichikawa $T$ and Matsumoto N. Influence of thermal cycles in water on flexural strength of laboratory-processed composite resin. Journal of Oral Rehabilitation. 2001; 28(8):703-7.

17. Munack J, Haubert H, Dogan S and Geurtsen W. Effects of various storage media on surface hardness and structure of four polyacid-modified composite resin (“compomers"). Clinical Oral Investigations. 2001; 5(4):254-9.

18. Gonçalves TS, Spohr AM, de Souza RM and Macedo de Menezes L. Surface roughness of auto polymerized acrylic resin according to different manipulation and polishing methods. The Angle Orthodontist. 2008; 78(5):931-4.

19. Silva Filho CE, Silva EMM, Sundfeld MLMM, Zequeto MM, Marchiori AV and Carvalho AM. Avaliação da rugosidade superficial de resinas acrílicas submetidas à ciclagem térmica. Revista de Odontologia de Araçatuba. 2006; 27(1):28-33.

20. Yilmaz A and Bayda S. Fracture resistance of various temporary crown materials. The Journal of Contemporary Dental Practice. 2007; 8(1):4451.

21. Goiato MC, Naves JC, Bressan RN, Santos DM, Fajardo RS and Fernandes AUR. Efeito de técnicas de polimento na porosidade e na dureza de resinas acrílicas submetidas a termociclagem. Revista de Odontologia da UNESP. 2006; 35(1):47-52.

22. Botega DM, Sanchez JL, Mesquita MF, Henriques GE and Consani RL. Effects of thermocycling on the tensile bond strength of three permanent soft denture liners. Journal of Prosthodontics. 2008; 17(7):550-4.

23. Anfe TEA, Caneppele TMF, Agra CM and Vieira GF. Microhardness assessment of different commercial brands of resin composites with different degrees of translucence. Brazilian Oral Research. 2008; 22(4):358-63.

24. Rueggeberg FA. From vulcanite to vinyl, a history of resins in restorative dentistry. The Journal of Prosthetic Dentistry. 2002; 87(4):364-79.

25. Kwon YH, Jeon GH, Jang CM, Seol HJ and Dim HI. Evaluation of polymerization of light-curing hybrid composite resins. Journal of Biomedical Materials Research. Part B, Applied Biomaterials. 2006; 76(1):106-13.

26. Ferracane JL. Hygroscopic and hydrolytic effects in dental polymer networks. Dental Materials. 2006; 22(3):211-22. 
27. Neisser MP, Goes MF, Rollo JMA and Consani S. Efeito da ciclagem térmica na determinação do coeficiente de expansão térmica e dureza Knoop de compósitos odontológicos. Revista de Odontologia da UNESP. 1997; 26(2):369-86.

28. Azzarri MJ, Cortizo MS and Alessandrini JL. Effect of the curing conditions on the properties of an acrylic denture base resin microwavepolymerised. Journal of Dentistry. 2003; 31(7):463-8.

29. Urban VM, Machado AL, Vergani CE, Giampaolo ET, Pavarina AC, de Almeida FG et al. Effect of water-bath post-polymerization on the mechanical properties, degree of conversion, and leaching of residual compounds of hard chairside reline resins. Dental Materials. 2009; 25(5):662-71.

30. Azevedo A, Machado AL, Vergani CE, Giampaolo ET, Pavarina AC and Magnani R. Effect of disinfectants on the hardness and roughness of reline acrylic resins. Journal of Prosthodontics. 2006; 15(4):235-42.

31. Barbosa GKS, Zavanelli AC, Guilherme AS and Zavanelli RA. Efeito de diferentes técnicas de acabamento e polimento sobre a rugosidade superficial de resinas acrílicas utilizadas para restaurações provisórias. Ciência Odontológica Brasileira. 2009; 12(1):15-22.

32. Jorge JH, Giampaolo ET, Vergani CE, Machado AL, Pavarina AC and Carlos IZ. Biocompatibility of denture base acrylic resins evaluated in culture of L929 cells. Effect of polymerisation cycle and postpolymerisation treatments. Gerodontology. 2007; 24(1):52-7.
33. Campanha NH, Pavarina AC, Giampaolo ET, Machado AL, Carlos IZ and Vergani CE. Cytotoxicity of hard chairside reline resins: effect of microwave irradiation and water bath postpolymerization treatments. The International Journal of Prosthodontics. 2006; 19(2):195-201.

34. Ilie $\mathrm{N}$ and Hickel R. Macro-, micro- and nano-mechanical investigations on silorane and methacrylate-based composites. Dental Materials. 2009; 25(6):810-9.

35. Söderholm KJ. Degradation of glass filler in experimental composites. Journal of Dental Research. 1981; 60 (11):1867-75.

36. Alves PV, Lima Filho RM, Telles E and Bolognese A. Surface roughness of acrylic resins after different curing and polishing techniques. The Angle Orthodontist. 2007; 77(3):528-31.

37. Tacir IH, Kama JD, Zortuk M and Eskimez S. Flexural properties of glass fiber reinforced acrylic resin polymers. Australian Dental Journal. 2006; 51:52-6.

38. Bollen CML, Lambrechts $\mathrm{P}$ and Quirynen M. Comparison of surface roughness of oral hard materials to the threshold surface roughness for bacterial plaque retention: a review of the literature. Dental Materials. 1997; 13(4):258-69.

39. Zissis AJ, Polizois GL, Yannikakis SA and Harrison A. Roughness of denture materials: a comparative study. The International Journal of Prosthodontics. 2000; 13(2):136-40. 
